\title{
TIME AT ITS MARGINS: Cattle Smuggling across the India-Bangladesh Border
}

\author{
MALINI SUR \\ Western Sydney University \\ (iD) https: / / orcid.org/0000-0002-5744-9648
}

After learning that the broker Jokhim had arranged a "signal clear" for the transport of six bulls across the India-Bangladesh border, the cattle transporter Alibaba had no time to speak to anyone. Indian border commanders who had accepted Jokhim's bribes had verbally granted a signal, which Jokhim relayed to Alibaba by rushing to his house. A signal clear comprises a precious two-to-three-hour window of opportunity during which Indian cattle workers such as Alibaba can cross the border to Bangladesh with their animals."Signal clear," Alibaba said to me, tying his cotton gamosa (towel) around his head as protection against the heat and the rain. During signal times he did not engage in useless banter pretending to be a bepari (trader), when he was really a trusted kamla (transporter). To acquire Alibaba's services, Bangladeshi cattle traders arrived at his modest one-room house in a remote village in the Indian state of Assam, situated about a mile away from the India-Bangladesh border.

Cows are politically significant animals, for one because Hindu nationalists in India consider them sacred. Despite having one of the largest cattle populations in the world, India does not export live cows, bulls, or buffaloes. ${ }^{1}$ Since direct diplomatic efforts have failed to convince India to export cattle legally, Bangladesh, a Muslim-majority country with a high demand for beef, especially, among the up-

CULTURAL ANTHROPOLOGY, Vol. 35, Issue 4, pp. 546-574, ISSN 0886-7356, online ISSN 1548-1360. (C) American Anthropological Association 2020. Cultural Anthropology journal content published since 2014 is freely available to download, save, reproduce, and transmit for noncommercial, scholarly, and educational purposes. Reproduction and transmission of journal content for the above purposes should credit the author and original source. Use, reproduction, or distribution of journal content for commercial purposes requires additional permissions from the American Anthropological Association; please contactpermissions@americananthro.org.DOI:10.14506/ca35.4.03 
per middle classes, has set up twenty-six animal-import corridors along its borders with India. Here, Bangladeshi border forces unilaterally "legalize" smuggled cattle by imposing a fine of US $\$ 2$ per cattle head. The printed receipt the Bangladeshi troops hand over to the traders constitutes a legal loophole allowing cattle transport and sale all over the country.

For Alibaba and Jokhim, who reside in the borderland chars — silted depositions and settlements created and recreated by the shifting course of the Brahmaputra and the Jinjiram Rivers - signals from Indian troops set into motion a series of activities. During signal clear, they lead the animals from Assam across the border to the adjoining Kurigram District in Bangladesh. Alibaba gathered the stocky bulls, colloquially known as home gorus, from a secret enclosure; his sharp stick landed on their humps, forcing them to nervously break into a run. Much like the English word signal, the word home has been domesticated to refer to cattle bred locally in the region. The dynamics of small-scale smuggling in home gorus that I discuss here, entirely dependent on the border commanders, stands apart from the movement of high-value and massive Zebu bulls that arrive from northern and western India to Assam. Smuggling in Zebu cattle involves a bigger network, with these animals arriving in large numbers, exceeding legal trade and consumption within Assam, expressly for smuggling to Bangladesh (Sur forthcoming).

When Indian soldiers escalated their surveillance over India's newly constructed border fence and intensified their search for political dissidents in the state of Assam, Jokhim's negotiations with the border forces would prove ineffective. The closure of border gates generated what I call armed times, times of imminent danger that would last from a few days to a month. During such periods of heightened state control, Indian border troops intensely surveilled cattle markets, border villages, and the border itself. Heavily armed soldiers searched markets to arrest Assamese political dissidents, whom they alleged acquired illicit firearm supplies from Bangladeshi cattle smugglers. The soldiers were also on the lookout for Bangladeshis, suspecting them to be smugglers, terrorists, or unauthorized migrants seeking to resettle and occupy land in Assam. Since 2014, under India's Hindu nationalist Bhartiya Janata Party (BJP)-led government, and the rise of the BJP to power in the state of Assam in 2016, the political revival of the gau mata (mother cow) as a revered Hindu symbol and the mushrooming of "Gau Rakshaks" (cow protectors) has led to tighter controls over cattle smuggling to Bangladesh. The resurgence in cow protection generates new temporal rhythms.

New armed times now last for as long as three months. During the extended suspension of opportunities for signal clear, cattle workers can either wait in- 
definitely for armed time to ebb-and subject themselves and their children to hunger - or they can risk torture, imprisonment, or being shot by Indian border troops while swimming across the rivers with the cattle. As the days stretched interminably during newly protracted armed times, Alibaba's gamosa remained carelessly thrown over his shoulder. The animals waited in hidden enclosures, often without food and water. No one knew when the border gates would open again.

How do borders structure the lived experience of time? How do borders reorder the linear measures of national histories? In addressing these questions from the 2,545-mile India-Bangladesh border, I relocate the study of time in anthropology, moving it from the comparative scholarship of internally coherent religious and national bodies to the very margins of religions, nations, and capital. ${ }^{2}$ Borders recalibrate time, imbuing mundane economic activities with political salience. The case of cattle smuggling demonstrates how, at the India-Bangladesh border, time proves erratic. The confluence of the cow's sacredness, the militarization of national sovereignty in India, and the militarized legalization of smuggled cows in Bangladesh expands and contracts time unpredictably, in ways that generate state violence. In dangerous border crossings, the shifting relationships between the sacred and the material embodied in home gorus shape the labor and value of the cattle trade. If the border's life-giving properties ensure the mobility of capital, people, and animals, its coercive temporal energies prolong hunger, dispiritedness, and death. The border makes time calculations fundamental to earning a living, setting new terms on which Muslim cattle workers, and the animals they trade in, will live and die. ${ }^{3}$

In this article, I open the labors of cattle smuggling to close ethnographic inquiry. I show how cattle's unique symbolism in India, India's new border fence construction, and Bangladesh's animal corridors contribute to disruptions in the progression of time: an erratic syncopation has replaced a previously predictable cycle of signal clear announcing times for border crossings. Consequently, as I demonstrate, people's experiences of the space of the border, both the mundane and the exceptionally violent, are essentially informed by fractured, shifting, and contingent experiences of time at the border. Borders thus constitute temporal as well as spatial phenomena.

In what follows, I briefly engage with the anthropology of time in relationship to the rhythms and structures of pastoral societies, nation-building, and capital to show how time and time calculations prove vital to surviving the violence that constrains the mobility of the cattle workforce along the India-Bangladesh border. I then explore the lives and livelihoods of Muslim cattle workers in India, 
demonstrating their negotiations with border outposts for smuggling signals. Their struggles and border crossings redraw the lines of national histories and economies. Next, I argue that the legalization of smuggled animals in Bangladesh makes cows and bulls mobile and high-value commodities; these arrangements ensure that Bangladeshi traders who have the upper hand in cattle transactions can speed up time to their benefit. Finally, I analyze the rise of a new politics of cow protection under India's BJP-led government that harnesses sacrality to reshape the tapestry of time. These policies intensify risks without preventing cattle smuggling.

\section{THE BORDERS OF TIME}

Anthropologists have closely attended to time's manifestations through rituals, values, nature, and capital. Time regulates economic activities and political and cosmological governance (Leach 1961; Geertz 1966; Evans-Pritchard 1969; Burman 1981; Munn 1992); it shapes nation-building and national histories (Chatterjee 1993; Hoskins 1997) and structures capitalist value and governmentality (Bear 2016; Yeh 2017). E. E. Evans-Pritchard's (1969) ethnology of the Nuer in southern Sudan immortalized cattle as pivotal to the study of time in anthropology. For the Nuer, a constellation of pastoral communities, Evans-Pritchard showed how time materialized through a sequence of tasks surrounding the care and pasturing of cattle, tasks rooted in local ecologies and seasons. In his analysis, cattle shaped Nuer time-consciousness as well as labor; the animals were a social force that united tribes in structural interrelations. The shared temporalities of cattle gave cohesion to Nuer life, while cattle's value simultaneously reinforced political boundaries between the Nuer and neighboring tribes such as the Dinka. In other words, cattle proved vital to the structuring of daily life and territoriality in this pastoral community (Evans-Pritchard 1969, 104-7). In pastoral societies more broadly, cattle determine the tempo of economic actions and notions of property, as well as strife (Ferguson 1985; Comaroff and Comaroff 1990; Straight 1997).

Unlike the Nuer time reckoning described by Evans-Pritchard (1969), where the animals' bodies and life cycles functioned as a force to structure social time, along the India-Bangladesh borderlands the smuggling in bulls and cows has emerged as a response to shifting dynamics between "imagined communities" of humans (Anderson 1991). And whereas Evans-Pritchard's celebration of the cultural specificities of Nuer cattle-clocks came to depoliticize time, as his characterization of the Nuer was timeless and lacked history, the crafting of national territories in the Indian subcontinent and the consolidation of India's borders came to transform the cow into an intensely political animal. 
Janet Hoskins's (1997) insights on time-reckoning among the Kodi in Indonesia offer a rich synthesis of how agricultural undertakings that closely followed ritual calendars stood in disjuncture with the timescale of the Indonesian nation-state. Notions of biographical time embedded in the value of objects and animals that composed local historical forces did the same. This disjuncture made local notions of heritage and national history distinct forces (Hoskins 1997). At the India-Bangladesh borderlands, this sense of dislocation has been historically evident as the lifeworlds of cattle extended far beyond narrow notions of religious nationalism and its political mobilization. In India, given cattle's distinctive place in religion, Hindu nationalist politics, which centers on cow protection, seeks to obliterate the diverse ways in which cows, bulls, and buffaloes hold value on the hoof, bone, and hide. These values are fundamental to pastoral and agrarian life, and by sustaining marginal communities in the borderland chars, they remain intrinsic to the experience of border times. Contemporary notions of sacrality rooted in nationalist histories continue to perpetuate an intensely material timescape at the border.

That nations produce asymmetric times - with past, present, and future neither in linear relation to one another nor neatly linking to a shared sense of identity, nationhood, or progress — is made evident in Partha Chatterjee's (1993) rendering of the exclusions generated by nationalism. Marginal subjects and subjectivities are ever palpable at the edges of nations. National borders make the very experience of time a profoundly fragile and ever-changing phenomenon (Andersson 2014, 804). Here, state control of unauthorized migration, the construction of border infrastructures, deportations, and human rights violations make temporal registers uncertain for undocumented migrants and border residents (Coutin 2005; Boehm 2009; Yeh 2017). If recasting scholarly attention on the nation's margins has established how exclusion exercises force by producing a duality of shared and divergent histories (Cons and Sanyal 2013, 7-8), it remains to be explored how borders reshape the temporal limits of national territories by splintering the experience of time. In other words, I am suggesting, time consciousness at borders is vital to our understanding of nations and nationalism.

Temporal gridlocks prove especially potent in frontier locations embedded in specific histories of capitalist mobility; at such sites, speed accelerates time to transform into a value in its own right (Yeh 2017). As contrasted with earlier formulations of capitalist modernity, Laura Bear (2014) shows how capitalist circulations fill modern time with doubt, conflict, dilemmas, and orchestrations. Departing from capitalist modernity that posit modern social time as situated in rou- 
tines and mediations, Bear argues that changing labor dynamics in contemporary modernity lay bare and work to resolve disparate social rhythms and representations of time, including nonhuman times (Bear 2014, 6, 20, 22). As a temporal divider, the India-Bangladesh border continues to mark cows as venerable animals. Yet cattle times are controlled not by bovine life cycles, but by the actions of affluent, "animal tax" paying Bangladeshi traders who demand cattle in a hurry and Bangladeshi troops who legalize cattle. They prod Indian cattle workers to move fast, even with high risks to life. High demand and price differentials drive the risky movement of cattle workers and animals, pushing their sales. The contrasting notions of the cow's sacrality and the use of cows, bulls, and buffaloes in everyday life provide the impetus for smuggling, reinforcing a material world of trade and strife. Illicit cattle passages sustain villagers while intensifying the risks of crossing a lethal border.

The specific modalities of cattle smuggling intrinsically tied to time calculations are inseparable both from state violence and from the new economies and social arrangements that rupture prior bonds of trust and kinship. Here, too, the boundaries of religions - especially Hindu and Muslim - in forming oppositional communities and nations further structure border policing. Where the India-Bangladesh border cuts through the chars of Assam and Kurigram, threats to India's national security plants the seeds of suspicion and results in the harassment of Muslim border residents. In April 2007, when I began fieldwork in the border chars, Indian troops shot 119 Bangladeshi and 23 Indian border crossers; the majority of those killed in cross-border firings were Muslim small-scale cattle traders and transporters like Alibaba (Human Rights Watch 2010, 10-13, 66, 78).

In this sense, the border functions as a "chokepoint - a site of constrictions - that disrupts as well as makes possible the terms on which life depends (Carse et al. 2020). Chokepoints are not just geographical locations; rather, they constitute temporal phenomena, facilitating and impeding the circulation of people and goods in time (Cons 2020,6). Two seemingly divergent infrastructuresIndia's new border fence and Bangladesh's animal corridors - modulate the progression of time, shifting it from cyclical beats to irregular rhythms. Engineers and construction firms responsible for building India's border with Bangladesh, and Indian soldiers who, in guarding the new barrier, fluctuate between signal clear and armed times, disrupt the flows of the cattle trade. Signal clear means sustenance for the traders but also quick deaths for well-fed bulls, whereas armed times lead to anxious waiting, scarcity, and violence for the traders and their families, as well as to the prolonging of animal lives before their inevitable slaughter. 


\section{SIGNAL CLEAR}

As soon as Alibaba said "signal clear," Badshah, his three-year-old son, would mimic his excitement. Pretending to be a trader, Badshah would hold a borrowed mobile phone and scream: "Hallo hallo_-signal clear, line clear?" In the border char where Alibaba and Jokhim resided, signals punctuated the routine rounds of border patrolling. Here, the border outposts — officially intended as insular militarized infrastructures, housing troops and weapons and functioning as the first line of defense during wars - grant signals and mediate everyday exchanges that revolve around the border (Sur 2019a).
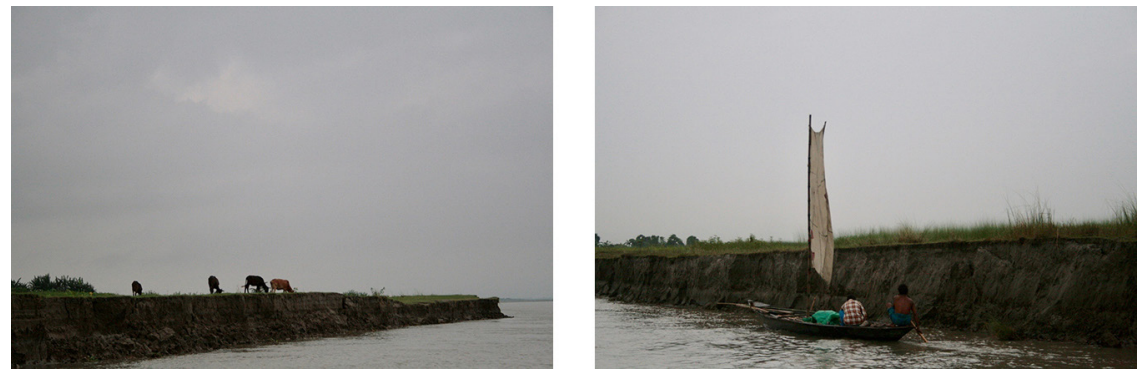

Figure 1 and Figure 2. Chars along the India-Bangladesh border. Photos by Malini Sur.

Ecologically, the border chars make for unstable territories. The changing course of rivers - such as the Brahmaputra and its numerous tributaries in Assam, as well as the Jinjiram in the Kurigram District of Bangladesh-both form and destroy these river islands composed of sand and silt. Residents laboriously reclaim the wetlands for cultivation and settlement - the forces of nature dictate life in these shifting regions. Although villagers carefully strive to make the chars cultivable and habitable, the returns from both agriculture and seasonal daily wage employment prove meager (Chakraborty 2009; Lahiri-Dutt and Samanta 2013; Khan 2014). Border chars are, however, not only ecological fragments; their locational fuzziness also make them economically productive sites. Rivers ensure that villagers can smuggle goods to make a living. In these areas, Indians and Bangladeshis share a predicament of being nodi bhanga manush, people whose lives and struggles are founded on the changing course of mercurial rivers.

In the chars, I rotated between the biweekly cattle haats, or markets, that occur on both sides of the border - during the day on the Indian side and during the evenings and nights in Bangladesh. I operated according to the circularity of time that straddled a dense network of places and relationships, which in turn 
revolved around cattle markets, border outposts, and animal corridors. In the state of Assam, cows, bulls, and buffaloes older than fourteen years and unfit for work and breeding can be legally slaughtered against a veterinary certificate; beef and buffalo meat, known as cara beef, are legally sold and consumed. Buffaloes are also sacrificed annually as a part of a specific Hindu temple ritual.

One day in Alibaba's char in Assam, I watched Jokhim wait unsuccessfully to gain entry to an Indian border outpost. Rumor had it that the Hindu commander-in-charge had moral reservations about transporting cattle for slaughter to Bangladesh, and even a bribe of US\$10 per cattle head would not suffice. Jokhim, however, did not give up. He waited for Khan, a new border constable, to walk out of the outpost on errands. Brokers like Jokhim carefully watched the arrival of young constables whom they believed more open to bribes - in his words, "more likely to swallow." Lighting a cigarette, Jokhim stood under a tree near the telephone booth on the highway. Alibaba fretted anxiously at a distance. As soon as Khan finished his phone call home and started off to complete his errands, Jokhim walked near, speaking to him without making eye contact. By the time Khan reached the border road, Jokhim had walked away, returning to Alibaba and another trader, Kazi.

By early evening, the camp had granted passage for a consignment of twenty cattle from three villages under its jurisdiction. At once, a frenzy of activity started. As soon as children heard their fathers uttering the English words "signal clear," they screamed in excitement, running out of their houses. Nasneen, Alibaba's wife, placed a wrapped betel leaf with nuts into his hand, giving similar pouches to their neighbors entrusted with the consignments. Then the men left. They walked for a mile or so before untying the stocky brown bulls from two shelters. At the border, Alibaba and others broke into a run, prodding the bulls with their sticks to cross quickly.

Signal clear propelled life into motion at the border. When signals were granted in quick succession, cattle workers and their families hardly slept. Indian kamlas ate once at home in the morning before sunrise and then again, long after sunset, either in their counterparts' house in Bangladesh or, on receiving another signal of clear passage, after they had returned home on the Indian side. On the Indian side of the border, sons, nephews, and neighbors quickly transported the cattle, running between brokers, positions of clearance, and areas where traders and cattle could gather to cross over to Bangladesh. Signals from India set Bangladesh's animal corridors into motion; cattle traders escorted the animals to tax counters, waited in queues, paid taxes, and then either sold the animals in cattle 
markets or kept them at home until they could strike deals with traders arriving from other districts.

Taking advantage of signal clear, small-scale Bangladeshi cattle traders like Chand and Karim Mia arrived in Assam to visit the cattle markets. Their hands were freshly painted with henna, a plant dye and auspicious symbol meant to protect their safe border crossings. One afternoon, Chand, Alibaba and I arrived in the cattle enclosure of a border haat located fifteen miles from Alibaba's char. We walked between the animals lining the congested enclosure, passing the heavily armed Indian border troops closely monitoring the market, guns and bullets strapped to their chests and wireless radios in hand. Chand stopped next to a herd of bulls, scrutinizing their size and mentally calculating the amount of beef that the animals would produce and the concomitant price it would fetch in Bangladesh. Such considerations determined whether he would purchase the animals. It was cheaper for Chand and Karim Mia to purchase the animals themselves and entrust Alibaba to arrange shelter and passage against a fee than to buy the animals for double or triple the price after Indian traders transported them to Bangladesh.
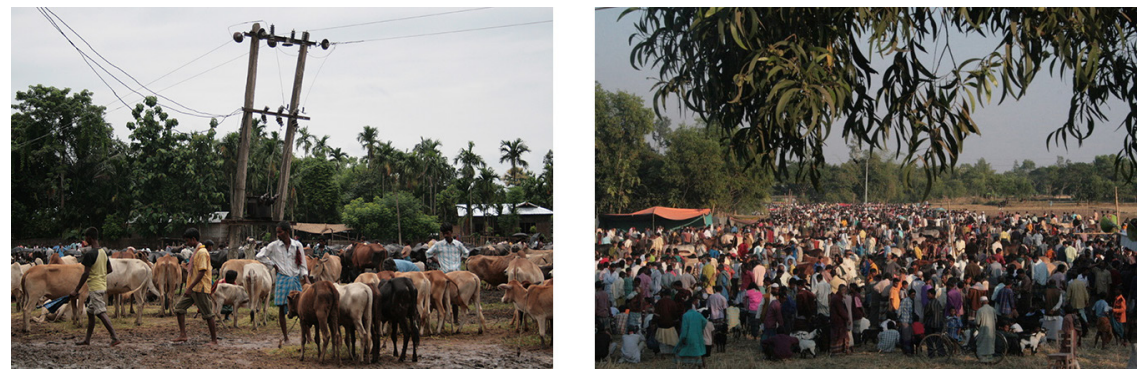

Figure 3 and Figure 4. Cattle markets along the India-Bangladesh border. Photos by Malini Sur.

Karim Mia spent his days visiting markets, always reminding his Indian friends that he was a legal trader who paid cattle tax. He invited me to visit Bangladesh and see for myself how the state and the border forces efficiently regulated the cattle business, telling me, "You should see how well organized the animal corridors are in Bangladesh. We are all doing legal business; the border forces manage the counters and we pay tax to the state." In the evenings, he relaxed with friends, often joking that one could never find his large shoe size in Indian markets. Mia's humor hid a confidently calculating mind that relied on the labor and goodwill of trusted transporters like Alibaba. Bangladeshi traders like him had the upper hand in time keeping. Given the legitimacy that Bangladesh's animal corridors afforded as a means of meeting upper middle-class demands for beef, leather, and ritual 
sacrifice, traders prodded time to move faster and faster to maximize the supply of animals. The regulation of India's border fence and Bangladesh's animal corridors constituted sophisticated capitalist relationships that accelerated time beyond the usual push for profit.

While traders and transporters moved between cattle markets on either side of the border, Alibaba's wife Nasneen in Assam and Chand's wife Dilshad in Kurigram paced outside their houses to locate mobile cell signals. Nasneen confirmed the passage of cattle from Indian chars to their Bangladeshi trading counterparts, patiently answering questions about changes in routes and delays over a phone she borrowed from her neighbor, also a cattle trader. Given the important role that women played in the trade, both Indian and Bangladeshi transporters and traders (roles taken by men) waxed eloquent about having women with "standards" in the family — meaning women who, as Alibaba put it, hosted his visitors with politeness and proved adept at persuasion. He had divorced his first wife, whom he had met during his border-crossing times as a youth, mostly because she was "lazy" and without the said standards. Chand joined the conversation, adjusting his red scarf and emphasizing: "Having a standard woman in the family like Dilshad adds value to the business - especially one who has the standards to speak to people, to host visitors, to cook for them, and attend to phone calls."

Nasneen and Dilshad lit their clay ovens to attend to both local and foreign visitors, feeding traders and transporters from well-stocked kitchens with supplies of rice and vegetables, and sometimes even buffalo meat in Assam and fish in Kurigram. Women's actions in creating "spatiotemporal transformations" — as Nancy Munn (1986) describes in the case of Gawa-function as critical parameters for forging a sense of community beyond the self. Munn reminds us that although women did not acquire fame, unlike the men whose self-transformation through the transmission of food to foreign visitors furthered trade exchanges, their role and powers of persuasion were central to kinship, relationality, and trade for the future (Munn 1986, 8-11, 52-53). Similarly, the gendered roles of persuasion meandered time for cattle passage across the India-Bangladesh borderlands. Nasneen and Dilshad did not attend to the cattle at any point of their transit. Yet their ability to extend time for passage and profits, and their labor in attending to the workers, reinforced cattle's value as a mobile commodity.

Signal clear was an industry in itself. It reconfigured time cycles, created new markets, and fostered exchanges. That cattle could exchange hands despite legal and infrastructural barriers expanded people's temporal horizons; signal times enabled impoverished cattle workers to imagine new futures. Alibaba desired to 
become a trader of the large, expensive Zebu bulls that arrived in these borderlands from northern and western India; Chand wanted to buy an Enfield "Bullet" motorbike, which he promised he would take to his grave; and Nasneen aspired to own a water pump right outside her house. Smuggling also energized children, with the promise of full plates of food, and other villagers, with the potential of employment. Children waited in anticipation of their fathers purchasing eggs and, with a little luck, even buffalo meat.

\section{CATTLE RUSTLING AND BORDER-MAKING}

Traders interpreted the clearance for cattle passage as an explicit acknowledgment of the long-standing professions of herders, tanners, traders, and butchers in the borderland whose lives revolved around the use and exchange of cattle across political boundaries. Between rushing around, traders and their families traced genealogies of trading. Chand would emphasize that traveling across the border chars resembled moving between two similar districts, not countries; both Alibaba's and Nasneen's fathers had also traded in cattle. In fact, as Alibaba nonchalantly conveyed to me one day, Nasneen's father was imprisoned in the district jail for murder over a failed cattle deal.

Official records stored in this region's dusty archives confirmed the long history of cattle rearing, rustling, and trade. In British India, cattle were ubiquitous as highly movable property, with cattle theft and recovery negotiated in diverse ways (Gilmartin 2003, 36-37). Since the late nineteenth century, cattle trading and slaughter occurred alongside the Hindu nationalist movements, which harnessed the cow's differential positioning _ as alive and godly for the Hindus and as sacrificial and food for Muslims - for mass mobilization. Through this process, Hindu nationalists transformed the animals into a political tool to protest the British colonial state in India, unite a dispersed Hindu community, and emphasize the differences between Hindus and Muslims in irreconcilable terms (Robb 1986; van der Veer 1994; Hansen 1999). Hindu nationalists politically invested the body of the cow with divinity; the animal came to embody both Hindu cosmology and a proto-nation. As a representative of Hindu identity and nationality, cows were seen to require protection from non-Hindus (Pinney 1997, 481-83).

Despite the political leverage of cows in the fight for separate homelands for Hindus and Muslims, their use for trade and exchange persisted. Cattle consignments arrived from northern India to the eastern borderlands, where they went on display in numerous cattle fairs. In the early twentieth century, British veterinary officers eagerly awaited the arrival of trains with large consignments of milch 
cows and bulls from Bihar, in high demand in these riverine borderland regions because the locally bred, smaller cattle proved unsuited for agricultural traction and carts. Further, the riparian landscape did not allow for breeding and grazing large herds of cattle (Blackwood 1915).

In August 1947, amid large-scale violence and displacement, the densely interconnected landscape of chars transformed into India and Pakistan with the partition of the Indian subcontinent. Pakistan's territory was further bifurcated, with the part known as East Pakistan separated from West Pakistan by Indian territory. The mobility of land, as in the form of shifting char settlements, posed additional territorial dilemmas, and the new nation-states aggressively claimed these regions (Chatterji 1999). India restricted live cattle exports and differentially prohibited and regulated cow and bull slaughter and transport even within the country. Along India's border with East Pakistan — which today includes regions that Alibaba and Chand traverse-competing claims over resources made cattle a precious resource for agricultural traction, trade, food, and leather. Ranchers, herdsmen, traders, and tanners who struggled to maintain their livelihoods had to make sense of how the newly imposed border could become of use to them (van Schendel 2005). Trans-border cattle raids were not just survival strategies in these regions but actions that delineated the margins of national territories at a time when even nation-states remained unsure about the precise location of the border. ${ }^{4}$

In its official records of border issues, East Pakistan came to classify and criminalize low-caste Hindu ranchers and herdsmen and indigenous communities as "notorious cattle lifters." Official deliberations on cattle raids and thefts between East Pakistan and India were remarkably devoid of religious overtones in the 1950s. ${ }^{5}$ The political location of cows and bulls at the border differed from other commodities such as rice, which was important as a precious food grain. India and East Pakistan used rice and rice taxation not only to demarcate national territories, ethnicities, and religions but also to evict and deport peasants through oppressive taxation and state repression (Sur 2016).

Although the Indian Customs Act (1962) permitted cattle exports with a license, cattle remain categorized with camels and horses as "restricted items." In effect, this regulation implies that no trade licenses are ever issued for live animals. Despite legal prohibitions, cattle transactions received a boost after the former East Pakistani territory emerged from the Liberation War as an independent Bangladesh in 1971. The continuing journeys of cattle traders and transporters across borderland chars attest to the economic value of cattle in a region where the sacred has a long history of being profane. Notwithstanding friendly diplomatic relations, 
India has refused to legally export cattle to Bangladesh. Still, retired Bangladeshi and Indian cattle traders recounted to me how cordial diplomatic relations had initially ensured an open border that had allowed for the routine occurrence of cattle exchanges across borderland haats. Trans-border trading waned between 1974 and 1979, due both to political instability in Bangladesh and to the emergence of anti-foreigner agitation in Assam known as the Assam Movement (Hussain 1993). After the agitation ended, cattle smuggling resumed. In fact, India continues to be a leading exporter of carabeef (buffalo meat) even with the BJP's ascendance in national politics (Dhingra 2019).

In some Indian states that share a border with Bangladesh, such as West Bengal, Indian border outposts have imposed cattle ceilings and introduced identity cards for animals that need to be grazed close to the border. These arrangements have realigned the political power between village headmen and prominent community members who desire cattle passage across their villages and the Indian border forces. They have also created new forms brokerage and control (Cons 2016; Ghosh 2019). Along Assam's border chars the large deployment of mostly Hindu soldiers in the Indian Border Security Forces (BSF) — who sometimes refuse to allow cattle to cross India's newly built fence for reasons of religiosity-complicates cattle smuggling, but ways including bribes are found to facilitate this highly lucrative trade.

Diverse fiscal practices and the diffusion of political authorities in border zones structure sustenance and confer meaning to life and social legitimacies (Flynn 1997; Walker 1999; Chalfin 2001; Das and Poole 2004; Roitman 2004, 2005; van Schendel 2005; van Schendel and Abraham 2005; Ghosh 2011; Sur 2012). Villagers on both sides of the India-Bangladesh border felt that cattle smuggling generated employment and prosperity; in fact, everyone I spoke with believed that the business of cattle smuggling had reduced rustling and theft. Travel for smallscale trans-border trading called kacha bebsha (perishables), including locally bred cattle, is sharply distinguished from pakka bebsha (high-value and often contraband) trading in drugs, arms, alcohol, and precious metals. Border communities shun the latter, as it involves dealing with morally suspect and highly dangerous substances. Jason Cons (2016, 558), writing about enclaves at the India-Bangladesh border, argues that neither border territories nor border dwellers fit the precise constructions of logic and rule imposed by nations. By closely attending to struggles of livelihood and legitimacy along the India-Bangladesh border, he argues that border histories are far more than mere linear narrations of the past. So, too, I argue are 
the time calculations and time-consciousness of border dwellers that set such histories into motion in the first place.

In India, relationships between the state, people, and cattle transcend the binary of religion and economy that has fundamentally driven bovine politics in India, as well as set the intellectual terms on which these binaries have been reproduced (Adcock and Govindrajan 2019, 1099). The scholarship on cattle symbolism, privileging histories of the sacred, has largely failed to account for people's distinct temporal sensibilities and relationships to bulls, cows, and buffaloes as commodities on the Indian subcontinent. Radhika Govindrajan's (2018) analysis of bovine materiality in India has brought to light how cow vigilantism coexists with, and does not override, the ritual and agrarian economies of care that shape people's relationship with cattle as domesticated animals in India, including their sale for slaughter. India's electoral agendas focusing on "cow protection" — which seek to wipe out the livelihoods that center on cattle rearing and trade-make the everyday materiality of bovine-human relations complex and anxiety ridden (Govindrajan 2018).

In the India-Bangladesh borderland chars, such complexities bear on our understanding of borders as temporal barriers. Disruptions in the flow of time make cattle routes longer, escalate state repression directed at Muslim cattle workers, generate prolonged periods of scarcity, rupture kinship, and gender the experience of time by discounting women's significant role in cattle economies. Indian and Bangladeshi cattle workers also felt ambivalent about their relationship with the animals. None of them were directly involved in slaughtering the cattle, but neither did they have the time to take care of them as they would for domestic animals. The families I lived with in the chars occasionally slaughtered chickens or sacrificed a goat, but border villagers could not afford to ritually slaughter large, expensive animals or purchase beef for consumption. Moving through cattle markets and along the animal corridors, I found myself continually avoiding eye contact with the animals, an act that revealed my awareness of their final fate.

\section{ARMED TIMES}

Periodically, the cyclical beats of hurried signal clears are interrupted by armed times that might last for one to four weeks. The distribution of risks associated with smuggling became especially evident during the national celebrations of India and Bangladesh — such as Independence, Republic, and Victory Dayswhen, as the villagers noted, "not even an ant can crawl across the border." The 
buzzing of wireless radios in roadside eateries, cattle markets, and border villages announces the onset of armed times that suspend the possibility of signal clear.

When the civil engineering firms contracted to build India's new border fence with Bangladesh started digging up the chars, the emergent barrier imposed new, off-kilter rhythms. Senior officials regularly arrived to oversee the progress of the construction work. Camp commanders and intelligence agents kept a close watch over the site to prevent the pilfering of materials. While construction haltingly proceeded in some stretches and galloped in others, border patrolling intensified and additional outposts were built to house troops on both sides of the border.

Uniformed men in khaki, blue, and military green, guns swinging from their shoulders, appeared in the border markets frequented by Alibaba and Chand in Assam. Indian troops, other federally funded security agencies, and specialized weapons teams combed the cattle markets, anticipating trouble from dissident groups in Assam and intensifying their efforts to apprehend Bangladeshis who had traveled to India without the necessary documents. ${ }^{6}$ One day in August 2007, on the eve of India's sixtieth anniversary celebrations after independence, I was in a border market with Chand. A trader in his mid-forties, the amicable Chand was a popular figure in Assam's chars. As soon as he arrived from Bangladesh, traders and transporters in Assam competed for his time and attention in the hope of striking a deal with him. Adjusting the red scarf that he always wore around his neck during good times, but not while crossing the border, he also suggested to me that his popularity stemmed from his honesty, honoring deals, and making payments on time.

Amid the crowd in the cattle arena and the numerous tea stalls where cattle traders stopped for a break, a healer's loud microphone announced magical cures for ailments ranging from aching muscles to infertility. Suddenly, unusually loud sirens drowned out the sounds of the loudspeaker. Chand gulped down his tea, walking toward the cattle arena. I nodded to him somewhat inattentively, raptly listening to the exploits of a young Bangladeshi cattle trader, who was boastfully recounting how Indian cattle smugglers had twice kidnapped him for ransom.

When the story had come to an end, I slowly walked toward Chand, carefully wading my way between the animals through the monsoon slush. A young man approached Chand and whispered something to him, at which point Chand immediately lost his composure. Sweating profusely, his voice shook as he told me that the Indian border forces were on a special lookout for Bangladeshis. Nervously, sensing the danger he usually felt when crossing the border, he untied his red scarf and 
stuffed it into his pocket. Seeing his face cloud in reaction to the security forces' patrolling the cattle market, I sensed danger, too. Everything blurred. Behind us, Indian troops continued to patrol; one blocked my way and suspiciously sized me up. I stood out as the only woman, and an urban one at that, in a remote and aggressively male-dominated cattle market. I turned my eyes away from his gun as Chand and I slowly made our way from the cattle stall to the bus stand. The imminent danger heightened our sense of time. Time sped up; we needed to leave the market quickly. Instead of waiting until the cattle arena closed, as we usually did, to buy the unsold cattle for a lower price, our rapid heartbeats let us know that the time was now to get back to the relative safety of Alibaba's house. The sound of my heart drowned out the din of mooing cattle and haggling traders. On the bus, Indian security forces frisked passengers, and my fears as well as numerous checkpoints prolonged our journey. Late that night, anticipating that the border gates would shut indefinitely, Chand anxiously crossed over to his village without purchasing any cattle.

With the border gates closed, Chand lost both money and his youthful demeanor. As we sat in his courtyard in a remote char in Kurigram, he stated, "The border is a strange place these days; everything has shut down for Bangladeshis, we don't know whom to trust anymore." Even at a well-known place where Chand crossed regularly and had arranged chairs for Bangladeshi and Indian troops to sit on during official meetings, armed times now constrained his access to the border. During such moments, the border came to be situated in a violent past where the boundaries of religion-Hindu and Muslim - once again surfaced as significant. The border no longer made for an everyday resource to a livelihood.

Chand's failed deals and monetary losses in India meant that he could no longer purchase wooden shutters for the windows of his new house. Instead, tin sheets covered the gaps. Since he could not travel to India and purchase cattle himself, he had made an advance payment to Indian traders. While they claimed his money, they failed to transport his consignments. As his wife Dilshad lamented, lighting a clay oven and placing a pot of rice to boil, "they [his counterparts in India] now turn their face away when he arrives; security is also high these days ... they no longer host him.” From their courtyard, we could see India's emerging border fence with its newly planted metal rods, later to be laced with barbed wire.

Alibaba went to the market every morning to see if he could earn a few cents from loading and unloading goods, failing which he sat at the roadside looking vacantly at the sky. He waited for more trucks to arrive with goods in the early afternoon. As Alibaba and Chand anxiously hoped for the border gates to 
reopen, armed time stretched for nearly a month, a seeming eternity. Waiting can be a political predicament that renders people unproductive (Hage 2009; Andersson 2014; Khosravi 2017; Janeja and Bandak 2019). It is an enduring condition for those in chronic poverty; for those prohibited from participating in economic activities, the act of waiting imposes a sense of cruel boredom (O'Neill 2017, 15-16, 43). Prolonged unemployment extends time by preventing people from achieving the socially desired status of modernity and adulthood (Jeffrey 2010, 466, 468). As Atreyee Majumdar (2018, 56, 70) reminds us, as people's relationship to time shifts from speed to slowness and immobility, they experience alternating feelings of control and loss. Time marginalizes people and places by positioning them at the limits of capitalist modernity. Political and legal regulations unevenly distribute insecurity, danger, and hope in ways that force people to wait indefinitely for employment and sustenance; time's expansion pushes people into forms of "nonbecoming” (Khosravi 2017, 218-19).

State repression resulted in a depressed distancing from smuggling; during armed times, traders pretended that they or their fathers had never engaged in the cattle business - as if cattle trading had no history in this region. Then, on a gloomy winter afternoon, Chand suddenly reintroduced his father as a trader who had been imprisoned in Assam. Until then, most of his stories of travel and trade had rested on his own trans-border journeys and stories of rivalries and abductions that occurred and were resolved within the cattle-trading rings. But that afternoon, his father's biography was suddenly revised from cattle trader who had traveled to Assam for decades to one who had abruptly ended his border-crossing career. Armed times made Chand link the precarious present that revolved around India's border polices on unauthorized Bangladeshi migration with the past. Referring to the Assam Movement, he said, "that was in the late 1970s, and even now they are imprisoning and killing Muslim cattle traders . . . nothing changes.” Although Chand's father never spoke about his involvement in smuggling, his silence established how his imprisonment in Assam had made him fear the border. Despite his father's inability to cross the border anymore, and even after several failed deals in smuggling hybrid seeds and alcoholic cough syrups from Assam, the profits from bull smuggling had lured Chand into the trade amid the uncertain times.

\section{HUNGRY TIMES, VIOLENT TIMES}

The expansion of time at the India-Bangladesh borders chars transforms it from a thriving center of capital, profit, and employment into a site of scarcity and violence. Alibaba and Nasneen's son Badshah stopped playing to run inside the 
house and scream for food the morning I arrived from another village. I had temporarily left Alibaba's char and was residing in an uphill village since disruptions in cattle flows had made my otherwise well-established domesticity with traders and their families edgy. Nasneen's voice cracked as she spoke to me, covering her bruised jaw with her palm. Embarrassed both about the visibility of her bruise and the lack of tea at home, she asked if I wanted to pay a visit to her sister-in-law, Nakhoda, whose son also traded in cattle. Alibaba walked in the opposite direction to sit in the local market; he was neither concerned nor apologetic about the violence that he had perpetrated on Nasneen. Purchasing a packet of tea leaves, sugar, and biscuits from a local shop, Badshah, Nasneen, and I walked to Nakhoda's house, the last one along the border, which functioned as a transit point for traders, brokers, and even legal travelers who paid for meals and rest.

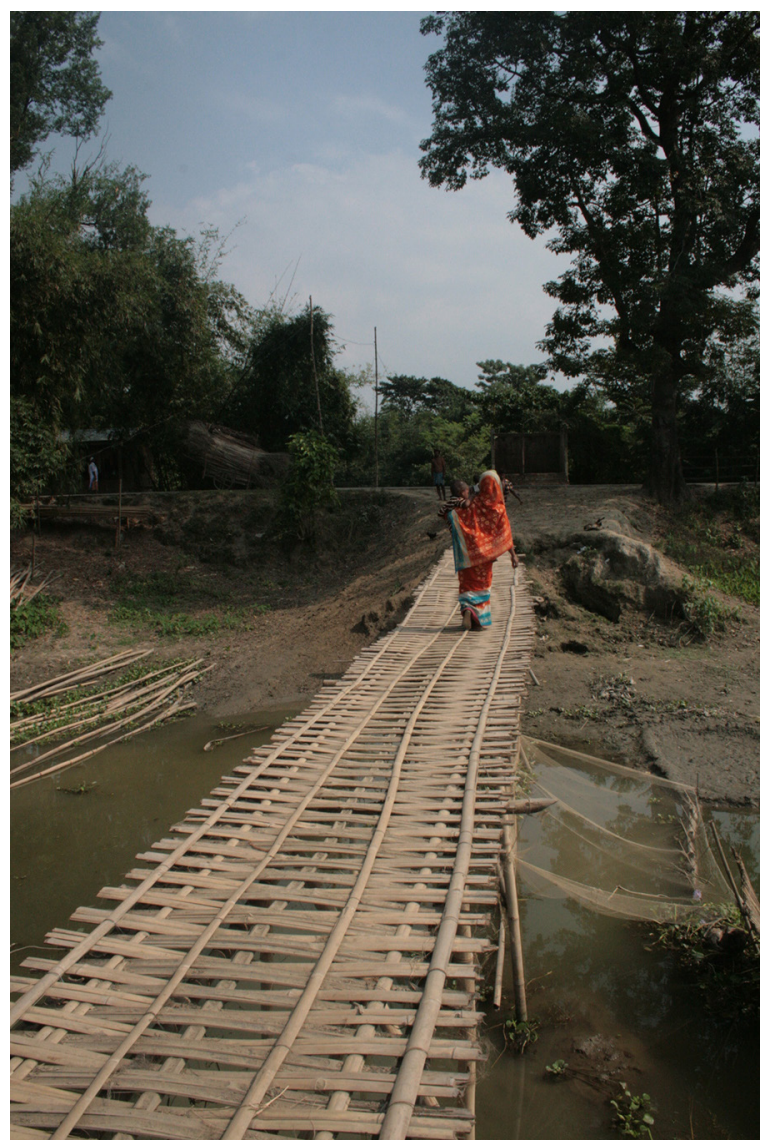

Figure 5. Nasneen and Badshah. Photo by Malini Sur. 
Seeing Nakhoda's adolescent son lick the last morsels of rice and lentils from his fingers, Badshah immediately demanded a plate of rice. Nakhoda pretended to scold me for bringing her the tea leaves while brewing tea with them. For the following hour, Badshah regularly interrupted our conversation, imploring his aunt for rice. Nakhoda smiled lovingly at her nephew but did nothing. Badshah cried again for rice. We chatted a while_-leading me to realize that, knowing that her sister-in-law had greater resources, Nasneen had intended to procure Badshah a meal. Nakhoda continued to engage him with verbal affection while remaining totally unmoved by his hungry cries. As we walked back, Nasneen softly cursed her sister-in-law while Badshah momentarily forgot his hunger and broke into a run. We returned home that afternoon with rice, eggs, and oil. Nasneen and I hurriedly cooked. Badshah ran into the kitchen demanding an entire egg for himself - it otherwise would be divided between him and his two elder siblings.

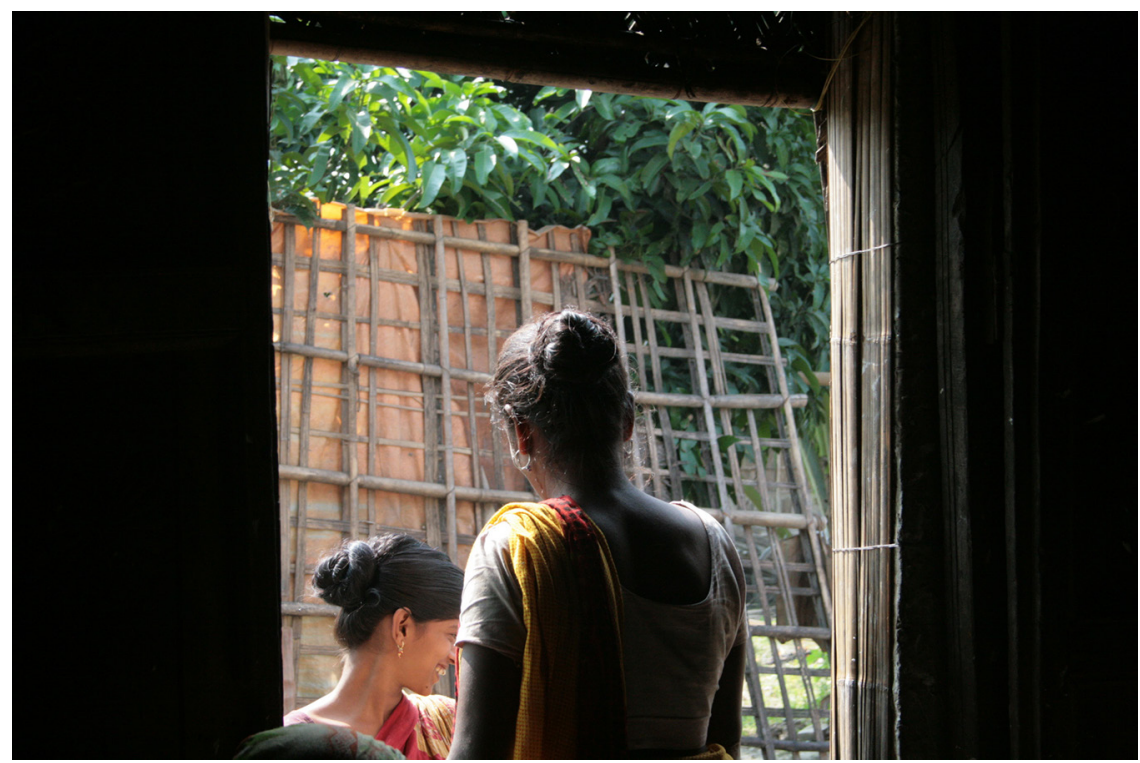

Figure 6. Nakhoda standing at her door. Photo by Malini Sur.

Sharon E. Hutchinson (1996) has shown how rapid political changes, famines, strife, and the imposition of government rules and courts in the 1980s had disrupted the remarkable harmony of Nuer marital relationships described by Evans-Pritchard in the 1930s. These had transformed men's prior social position as protectors of the hearth and cattle herd and had eroded women's roles as procreators who defined how blood, cattle, and food would make relationships. Men 
complained about losing control over their wives and daughters, while women spoke bitterly about abandonment, their husbands' seizing of domestic resources like cattle, and their struggles to gain control over essential supplies of food, medicine, and money. The symbolic relationship of blood and food that had reinforced vitality and vulnerability, and the sharing of food which had earlier sustained kinship, had now become unsettled (Hutchinson 1996, 158-60).

The crisis of food and thirst as Bhrigupati Singh (2015) avers, is indeed "slow moving." He advances that hunger and thirst occur at different speeds and temporalities: they are not just related to one significant catastrophic event. Across the borderland chars, hunger lingered through recurrent scarcity, rendering fragile the bonds of family and kinship. Delays in cattle passages reinforced kinship hierarchies, but not obligations. New calculations about resources and consumption made the familial and familiar exchange of food difficult. Disruptions in cattle flows unsettled both the sense of paternal pride in providing for the family and maternal responsibilities in relationship to food. No one knew when the border gates would open again; the border itself effortlessly shifted to a site of closure, suffering, and hunger. Scarcity had cut Nasneen off from kinship networks within her husband's family.

Today, armed times can persist up to three months and occur unpredictably. A resurgent politics of cow protection with the rise of India's BJP further entrenches hunger and disrupts social ties. New and erratic configurations make the time calculations for border crossings fraught with even more dangers. Under Assam's BJP-led state government, cow-protection policies have severely impacted the transport of animals. They disrupt even legal trade within the state. Instead of preventing cow smuggling, these policies have only led to a greater number of cattle seizures. ${ }^{7}$ Although the Bangladeshi government officially states that the smuggling of Indian cattle harms Bangladeshi dairy farmers and traders (Business Standard 2017), by continuing to operate the animal corridors, the state in fact condones its troops unilaterally legalizing smuggled animals. While earlier cattle workers oscillated between signal clear and armed times as distinct temporal experiences, in recent years fence construction, border shootings, and the unilateral legalization of cattle have made their distinctions blurry.

During new armed times, the high risk while crossing the border to human and animal lives becomes evident in instances of torture, incarceration, and the shooting of cattle workers and injuries to the animals by Indian troops. Furthermore, unauthorized migration from Bangladesh to Assam related to conflicts over land, language, and identity led to the updating of the National Register of Citizens 
in 2015, with the intention of weeding out suspected Bangladeshi foreigners. This bureaucratic exercise has made 1.9 million people stateless and has also eroded people's claims to Indian citizenship in the chars. During this time, India escalated troop deployment. Muslim traders and transporters were even more fearful of crossing the border. Relationships that had coalesced around smuggling in the devastating world of the chars suddenly became nationalist. In each country, smallscale cattle workers had differential access to the border. Although in India the border gates remained shut, Bangladeshi traders and troops continued to demand the delivery of cattle, since the animal tax legalized the trade for them. Indian troops granted signals at their discretion, favoring affluent villagers who traded in big consignments of the Zebu cattle that were in greater demand in Bangladesh for the large quantities of beef each animal produced. Those who failed to get clearance reported rival traders to the police. The disruption in time meant that cross-border journeys of barely two miles between one cattle market and another took weeks. When Indian outposts refused to relent and accept bribes, cattle workers' journeys extended and turned mostly nocturnal (Sur forthcoming).

The asynchronous motions of time that mark people as lawbreakers and places as crime-infested serve to justify state violence. Across the borderland chars the irregularity of legal restrictions and allowances made the experience of time uneven. It pushed workers to cross the border while risking potential torture, detention, and incarceration at the hands of Indian soldiers. The border released time's coercive forces to disrupt prior relationships of trust and affinity that had realigned notions of national territory. The consequences of armed times at the India-Bangladesh border were evident in partly constructed houses and empty kitchens and stomachs, and in violence that Indian troops perpetrated on the Muslim cattle workforce. As punishment Indian troops sometimes strung transporters and traders upside down from trees outside the border outposts. This torture meant to deter others from crossing the border. These incidents do not figure in the high estimates of human rights violations at the India-Bangladesh border. Between 2009 and 2019, Indian border troops killed 455, injured 657, and abducted 518 Bangladeshi citizens (see Human Rights Watch 2010; Ain o Salish Kendra n.d.). These incidents occurred while Indian and Bangladeshi commanders continued to facilitate the high-value trade in Zebu cattle (Sur forthcoming).

In calling attention to a distinct temporality of daily life, E. Valentine Daniel (1996) and Veena Das (2006) have raised important questions about violence and the recurrence of suffering. Violence halts the flow of time, producing what Daniel (1996, 127, 133-34) calls "arrested moments" yet to be channeled into the 
passage of time. Das (2006) shows how violent events generate a "field of force" within which later narratives nest. As a life-changing force, "time strikes" and "time showers great cruelties" to reshape the association between political transformations and social structures. Substituting time for space, Das (2006, 1, 9-11, 86-88, 198) takes "critical events" as an anthropological entry point to depart from privileging locality. The India-Bangladesh border unevenly gathers dispersed and violent national histories into unpredictable times; time realigns people's spatial and trans-border relationships. The force of the past transforms the bodies of cows and bulls into signs of a modern social imaginary of the Hindu nation protecting sacred cows in the present. Hindu nationalist and religious histories resurface as temporal forces that make cows revered and push impoverished Muslim cattle workers through a precarious present. Such times move the border troops to violence and transform feast into famine for children like Badshah.

Prolonged unemployment compelled transporters to cross borders despite the increasing threat to their lives. Alibaba used his knowledge of trans-border river geographies to circumvent the temporal regimes imposed by Indian border troops, without challenging them. Jokhim sensed the border for transporters. Time compressed as they took the final plunge and crossed the boundary without a signal. A week after Alibaba risked the unsignaled border-crossing, Nasneen and I heard gunshots. Soon, Alibaba returned with the news that the decomposing bodies of cattle transporters had been found floating in the Brahmaputra. No one claimed responsibility. Dead bodies floating on rivers and mutilated bodies found along border roads or hidden deep in jute fields emphasize India's nationalist postures against transgressive Muslim citizens and an Islamic Bangladesh (van Schendel 2005; Jones 2009, 889). Yet such graphic displays of violence mask the lucrative commercial transactions that benefit both the Indian border commanders who shoot at traders in between rent-seeking deals and the Bangladeshi border troops who meet the nation's demand for cattle with cold disregard for the lives of Bangladeshi cattle workers.

Violence reorders the experience of time. For me, the long hours and exhaustion from fieldwork that entailed negotiating distinct times for different kinds of smuggling blurred the boundaries of days and nights and fieldwork and writing. Even within the confines of the village homes where I resided, late at night, the noise of animals and the loud purring of transporting trucks filtered into my consciousness. Like the cattle workers whose struggles I intended to study and whose bodies seemed to be forever in motion, my body alternated between gaining momentum in sleep and sleep paralysis. The lingering effects of post trauma disori- 
ented my sense of time. It made my nights as bright as the days and my days as fearful and dark as the nights. I physically left the borderland in 2008 and returned to it between 2013 and 2015. During this latter period and after, the border and its humans and animals have continued to linger in my consciousness in unanticipated ways (Sur 2019b).

For small-scale Muslim traders and transporters and their families who, unlike me, have no recourse to elsewhere, state repression lingers in uncertain mobility and time beats. Writing about Palestinian immobility, Julie Peteet (2017) has shown how mobilities are located in a system of asymmetrical relationships. The imposition of what she describes as "calibrated chaos" reinforces categories of difference in ways that partition and govern access to space. The anticipation of torture and death, and the fears of crossing the border and the loss of livelihood, as I have shown, not only realign people's relationship to partitioned nation-states but also radically alter the cycles of time. During new armed times the unpredictable river waters that both enable the passage of cattle and also seasonally flood Alibaba and Chand's homes heighten their sense of time and loss. Lives and livelihoods are scarred and divided.

\section{CONCLUSION}

In this article I have shown how the unique sacrality ascribed to cows in India reshapes people's experience of time, nation, and capital. Borders bring into sharp relief the fictive bounding of time by nations and capital. They reveal the irregular beats of time-consciousness in a non-linear manner amid calculations that determine who will move, when, and under what circumstances. India's new politics of cow protection make the experience of time more fractured, ever changing, and contingent. In many ways time shapes the space of the border. In the chars, time shapes its use as a resource for smuggling. Such temporal predicaments recall Victor Turner's (1979) "liminal times" of "being-on-a-threshold." For Turner $(1979,465)$, the location of liminal times outside the temporal horizon of clock time was one of "enchantment when anything might, even should, happen." But at the India-Bangladesh border, zones of temporal indeterminacy pull the bodies of cattle workers toward disenchantment and danger and push the animals toward slow deaths. This relationship between time and violence is endemic to border societies and defines the anxious predicaments of undocumented border-crossers around the globe.

As the more insidious workings of nationalisms and arbitrary state power leave their imprints on the shifting landscape of the India-Bangladesh borderland 
chars, cattle passages reveal time as a force that both destroys life and enables its productive potential. Cattle smuggling thus indexes capital's unevenness and its emergent possibilities, collapsing the distance between national events and everyday life. Here, too, for children like Badshah, and families who depend upon cattle work, histories and genealogies resurface as forces that undergird the tension between time's non-linearity, precarious textures, and territorial dispersals.

\begin{abstract}
This article resituates the study of time in anthropology, moving it from the comparative exploration of internally coherent religions and national territories to the very margins of religions, nations, and capital. Borders recalibrate time by imbuing mundane economic activities with political salience. Dangerous border crossings make temporal registers contingent and erratic, and generative of violence and torture. I show how India's prohibitions on live cattle exports and Bangladesh's demand for beef compel acts that effectively legalize animal smuggling, which, nonetheless, remains a risky business. Across the riverine islands of the India-Bangladesh borderlands, smallscale traders and transporters operate according to the distinct logics of militarized infrastructures and legal regimes that generate moments of "signal clear," marking the temporary opening of border passages and opportunities for sustenance, as well as "armed" times, more sustained periods of heightened national security, and imminent violence. By subjecting the border's productive and coercive temporal energies to close ethnographic scrutiny, I suggest that cattle's sacrality reinforces the material world of capital and strife, ruptures kinship ties, and subjects Muslim cattle workers and their families to prolonged periods of scarcity and hunger. This article shows how people's experiences of the borderland as a space are vitally shaped by fractured, shifting, and contingent rhythms of time. [borders; time; value; cow smuggling; violence; kinship; gender; Assam; India-Bangladesh border]
\end{abstract}

\title{
NOTES
}

Acknowledgments I thank the editors and reviewers of Cultural Anthropology for their exceptionally insightful comments, especially Heather Paxson for her generous engagement. Maria José de Abreu, Prathama Banerjee, Eli Elinoff, George Jose, Eric Kerr, Rakesh Kumar, Geir Henning Presterudstuen, Willem van Schendel, and Emrah Yıldız offered incisive suggestions for earlier drafts for which I am grateful. I thank the audiences at the University of Amsterdam, the Asia Research Institute at the National University of Singapore, the American Anthropological Annual Meeting in San Jose, and Sarah Lawrence College. Bernard Bate's thoughtful commentary greatly shaped my thoughts in writing; I dedicate this article to his memory.

1. On the restrictions of cattle as livestock, see the Indian Customs Act, 1962, accessed May 11, 2018, http://exim.indiamart.com/act-regulations/customs-act-1962.html.

2. I conducted almost a year of fieldwork in 2007 and 2008, living in remote border villages in Assam and Meghalaya, Northeast India, and Kurigram, Sherpur, Jamalpur, Netrokona, and Mymensingh Districts in Bangladesh. I returned to the borderland in 2013, 
after the intensity of my post-traumatic stress had subsided, and continued fieldwork until mid-2015. I thank Rashid who accompanied me for fieldwork in Assam in 2007. I have used pseudonyms to protect all the identities of people mentioned in this article, including Rashid.

3. On how India's cow-protection policies impose discriminatory Hindu caste-oriented human values on animals, and how "casteised speciesism," ensures that exceptional violence is directed toward animals, see Yamini Narayanan (2018). On the interplay of the sacred and capital in the context of killing animals, and how time regulates which animals will meet a prolonged death or die quickly, see Bhrigupati Singh and Naisargi Dave (2015).

4. Government of East Bengal, Home political CR 3A-10/52; Government of East Bengal, Home (Political) CR 1B4-49/54; Letter No c.18/54/227, Shillong, August 9, 1954; Government of East Bengal, Home (Political) CRI B4-25/54 B.

5. Government of East Bengal, Home (Political) CR 1B4-49/54, 538-541.

6. For a comprehensive analysis of India's militarization of Assam, subnationalism, and the rise of political movements, see Sanjib Baruah (1999).

7. Between 2015 and June 2018, 61,297 cases of cattle smuggling were filed at the India-Bangladesh border (Human Rights Watch 2019).

\section{REFERENCES}

Adcock, Cassie, and Radhika Govindrajan

2019 "Bovine Politics in South Asia: Rethinking Religion, Law and Ethics." South Asia: Journal of South Asian Studies 42, no 6: 1095-107. https://doi.org/10.1080/008564 01.2019 .1681726$.

Ain o Salish Kendra

n.d. "Category Archives: Border Violence." Accessed March 7, 2020. http://www. askbd.org/ask/category/hr-monitoring/border-violence/.

Anderson, Benedict

1991 Imagined Communities: Reflections on the Origin and Spread of Nationalism. London: Verso.

Andersson, Ruben

2014 "Time and the Migrant Other: European Border Controls and the Temporal Economics of Illegality." American Anthropologist 116, no. 4: 795-809. https://doi. org/10.1111/aman.12148.

Baruah, Sanjib

1999 India against Itself: Assam and the Politics of Nationality. Philadelphia: University of Pennsylvania Press.

Bear, Laura

2014 "Doubt, Conflict, Mediation: An Anthropology of Modern Time." Journal of the Royal Anthropological Institute 20, no. S1: 3-30. https://doi.org/10.1111/14679655.12091.

2016 “Time as Technique." Annual Review of Anthropology 45: 487-502. https://doi. org/10.1146/annurev-anthro-102313-030159.

Blackwood, J. R.

1915 A Survey and Census of the Cattle of Bengal. Calcutta: Bengal Secretariat Book Depot. Boehm, Deborah A.

2009 “QQuien Sabe?’: Deportation and Temporality among Transnational Mexicans.” Urban Anthropology and Studies of Cultural Systems and World Economic Development Burman, Rickie 38, nos. 2/3/4: 345-74. https://www.jstor.org/stable/40553654.

1981 “Time and Socioeconomic Change on Simbo, Solomon Islands." Man 16, no. 2: 251-67. https://doi.org/10.2307/2801398. 
Business Standard

2017 "Illegal Cattle Smuggling from India Harming Bangladeshi Economy: BGB." Business Standard, July 15. http://www.business-standard.com/article/currentaffairs/illegal-cattle-smuggling-from-india-harming-bangladeshi-economybgb-117071500374_1.html.

Carse, Ashley, Townsend Middleton, Jason Cons, Jatin Dua, Gabriela Valdivia, and Elizabeth Cullen Dunn

2020 "Chokepoints: Anthropologies of the Constricted Contemporary." Ethnos. https:// doi.org/10.1080/00141844.2019.1696862.

Chakraborty, Gorky

2009 Assam's Hinterland: Society and Economy in the Char Areas. New Delhi: Akansha Publishing House.

Chalfin, Brenda

2001 "Border Zone Trade and the Economic Boundaries of the State in North-East Ghana." Africa: Journal of the International African Institute 71, no. 2: 202-24. https://doi.org/10.2307/1161520.

Chatterjee, Partha

1993 The Nation and Its Fragments: Colonial and Postcolonial Histories. Princeton, N.J.: Princeton University Press.

Chatterji, Joya

1999 "The Fashioning of a Frontier: The Radcliffe Line and Bengal's Border Landscape, 1947-52." Modern Asian Studies 33, no. 1: 185-242. https://doi.org/10.1017/ S0026749X99003066.

Comaroff, John L., and Jean Comaroff

1990 "Goodly Beasts, Beastly Goods: Cattle and Commodities in a South African Context.” American Ethnologist 17, no. 2: 195-216. https://doi.org/10.1525/ ae.1990.17.2.02a00010.

Cons, Jason

2016 Sensitive Space: Fragmented Territory at the India-Bangladesh Border. Seattle: University of Washington Press.

2020 "Delta Temporalities: Choked and Tangled Futures in the Sundarbans." Ethnos. https://doi.org/10.1080/00141844.2019.1697334.

Cons, Jason, and Romola Sanyal

2013 "Geographies at the Margins: Borders in South Asia - An Introduction." Political Geography 35: 5-13. https://doi.org/10.1016/j.polgeo.2013.06.001.

Coutin, Susan Bibler

2005 "Being En Route." American Anthropologist 107, no. 2: 195-206. https://doi. org/10.1525/aa.2005.107.2.195.

Daniel, E. Valentine

1996 Charred Lullabies: Chapters in an Anthropology of Violence. Princeton, N.J.: Princeton University Press.

Das, Veena

2006 Life and Words: Violence and the Descent into the Ordinary. Berkeley: University of California Press.

Das, Veena, and Deborah Poole, eds.

2004 Anthropology in the Margins of the State. New Delhi: Oxford University Press.

Dhingra, Sanya

2019 "India's Beef Exports Rise under Modi Govt despite Hindu Vigilante Campaign at Home." The Print, March 26. https://theprint.in/economy/indias-beef-exports-

Evans-Pritchard, E. E. rise-under-modi-govt-despite-hindu-vigilante-campaign-at-home/210164/.

1969 The Nuer: A Description of the Modes of Livelihood and Political Institutions of Nilotic People. New York: Oxford University Press. 
Ferguson, James

1985 “The Bovine Mystique: Power, Property and Livestock in Rural Lesotho.” Man 20, Flynn, Donna K. no. 4: 647-74. https://doi.org/10.2307/2802755.

1997 "We are the border': Identity, Exchange and the State along the Bénin-Nigeria Border." American Ethnologist 24, no. 2: 311-30. https://doi.org/10.1525/ae.1997. 24.2.311.

Geertz, Clifford

1966 Person, Time, and Conduct in Bali: An Essay in Cultural Analysis. New Haven: Southeast Asia Studies, Yale University.

Ghosh, Sahana

2011 "Cross-Border Activities in Everyday Life: The Bengal Borderlands." Contemporary South Asia 19, no. 1: 49-60. https://doi.org/10.1080/09584935.2010.544718.

2019 "Chor, Police and Cattle: The Political Economies of Bovine Value in the IndiaBangladesh Borderlands." South Asia: Journal of South Asian Studies 42, no. 6: 1108 24. https://doi.org/10.1080/00856401.2019.1672926.

Gilmartin, David

2003 "Cattle, Crime and Colonialism: Property as Negotiation in North India." Indian Economic and Social History Review 40, no. 1: 33-56.

Govindrajan, Radhika

2018 Animal Intimacies: Interspecies Relatedness in India's Central Himalayas. Chicago: University of Chicago Press.

Hage, Ghassan, ed.

2009 Waiting. Melbourne: Melbourne University Press.

Hansen, Thomas Blom

1999 The Saffron Wave: Democracy and Hindu Nationalism in India. Princeton, N.J.: Princeton University Press.

Hoskins, Janet

1997 The Play of Time: Kodi Perspectives on Calendars, History, and Exchange. Berkeley: University of California Press.

Human Rights Watch

2010 "Trigger Happy: Excessive Use of Force by Indian Troops at the Bangladesh Border." New York: Human Rights Watch.

2019 "Violent Cow Protection in India: Vigilante Groups Attack Minorities." New York: Human Rights Watch. https://www.hrw.org/report/2019/02/18/violentHussain, Monirul cow-protection-india/vigilante-groups-attack-minorities\#.

1993 The Assam Movement: Class, Ideology and Identity. Delhi: Manak.

Hutchinson, Sharon E.

1996 Nuer Dilemmas: Coping with Money, War, and the State. Berkeley: University of California Press.

Janeja, Manpreet K., and Andreas Bandak, eds.

2019 Ethnographies of Waiting: Doubt, Hope and Uncertainty. London: Bloomsbury Academic.

Jeffrey, Craig

2010 "Timepass: Youth, Class, and Time among Unemployed Young Men in India." American Ethnologist 37, no. 3: 465-81. https://doi.org/10.1111/j.1548-1425.2010. 01266.x.

Jones, Reece

2009 "Agents of Exception: Border Security and the Marginalization of Muslims in India." Environment and Planning D: Society and Space 27, no. 5: 879-97. https://doi.

Khan, Naveeda $\operatorname{org} / 10.1068 \% 2 \mathrm{Fd} 10108$.

2014 "Dogs and Humans and What Earth Can Be: Filaments of Muslim Ecological Thought." Hau 4, no. 3: 245-64. https://doi.org/10.14318/hau4.3.015. 
Khosravi, Shahram

2017 Precarious Lives: Waiting and Hope in Iran. Pennsylvania: University of Pennsylvania Press.

Lahiri-Dutt, Kuntala, and Gopa Samanta

2013 Dancing with the River: People and Life on the Chars of South Asia. New Haven: Yale University Press.

Leach, Edmund R.

1961 Rethinking Anthropology. London: Athlone Press.

Majumdar, Atreyee

2018 Time, Space, and Capital in India: Longing and Belonging in an Urban-Industrial Hinterland. New Delhi: Routledge.

Munn, Nancy D.

1986 The Fame of Gawa: A Symbolic Study of Value Transformation in a Massim (Papua New Guinea) Society. Cambridge, UK: Cambridge University Press.

1992 "The Cultural Anthropology of Time: A Critical Essay." Annual Review of Anthropology 21: 93-123. https://doi.org/10.1146/annurev.an.21.100192.000521.

Narayanan, Yamini

2018 “Cow Protection as 'Casteised Speciesism': Sacralisation, Commercialisation and Politicisation.” South Asia: Journal of South Asian Studies 41, no. 2: 331-51. https:// doi.org/10.1080/00856401.2018.1419794.

O’Neill, Bruce

2017 The Space of Boredom: Homelessness in the Slowing Global Order. Durham, N.C.: Duke University Press.

Peteet, Julie

2017 Space and Mobility in Palestine. Bloomington: Indiana University Press.

Pinney, Christopher

1997 "The Nation (Un)Pictured? Chromolithography and 'Popular' Politics in India, 1878-1995." Critical Inquiry 23, no. 4: 834-67. https://doi.org/10.1086/448856.

Robb, Peter

1986 "The Challenge of Gau Mata: British Policy and Religious Change in India, 1880-1916." Modern Asian Studies 20, no. 2: 285-319. https://doi.org/10.1017/ S0026749X00000846.

Roitman, Janet

2004 "Productivity in the Margins: The Reconstitution of State Power in the Chad Basin." In Anthropology in the Margins of the State, edited by Veena Das and Deborah Poole, 191-224. New Delhi: Oxford University Press.

2005 Fiscal Disobedience: An Anthropology of Economic Regulation in Central Africa. Princeton, N.J.: Princeton University Press.

Singh, Bhrigupati

2015 "Hunger and Thirst: Crises at Varying Thresholds of Life." In Living and Dying in the Contemporary World: A Compendium, edited by Veena Das and Clara Han, 576-98. Oakland: University of California Press.

Singh, Bhrigupati, and Naisargi Dave

2015 "On the Killing and Killability of Animals: Nonmoral Thoughts for the Anthropology of Ethics." Comparative Studies of South Asia, Africa and the Middle East 35, no. 2: 232-45. https://doi.org/10.1215/1089201x-3139012.

Straight, Bilinda

1997 "Gender, Work, and Change among Samburu Pastoralists of Northern Kenya." Research in Economic Anthropology 18: 65-91.

Sur, Malini

2012 "Bamboo Baskets and Barricades: Gendered Landscapes at the India-Bangladesh Border." In Transnational Flows and Permissive Polities: Ethnographies of Human Mobility in Asia, edited by Barak Kalir and Malini Sur, 127-50. Amsterdam: Amsterdam University Press. 
2016 "Battles for the Golden Grain: Paddy Soldiers and the Making of the Northeast India-East Pakistan Border, 1930-1970.” Comparative Studies in Society and History 58, no. 3: 804-32. https://doi.org/10.1017/S0010417516000360.

2019a "Danger and Difference: Teatime at the Northeast India-Bangladesh Border." Modern Asian Studies 53, no. 3: 846-73. https://doi.org/10.1017/S0026749X18000082.

2019b "Dreaming Borders: On Cats and Trauma." Somatosphere, February 1. http:// somatosphere.net/2019/dreaming-borders-on-cats-and-trauma.html/.

Turner, Victor

Forthcoming Jungle Passports: Fences, Mobility and Citizenship at the Northeast IndiaBangladesh Border. Philadelphia: University of Pennsylvania Press.

1979 "Frame, Flow and Reflection: Ritual and Drama as Public Liminality." Japanese Journal of Religious Studies 6, no. 4: 465-99. https://doi.org/10.18874/

van der Veer, Peter jjrs.6.4.1979.465-499.

1994 Religious Nationalism: Hindus and Muslims in India. Berkeley: University of California Press.

van Schendel, Willem

2005 The Bengal Borderland: Beyond State and Nation in South Asia. London: Anthem.

van Schendel, Willem, and Itty Abraham, eds.

2005 Illicit Flows and Criminal Things: States, Borders, and the Other Side of Globalization. Bloomington: Indiana University Press.

Walker, Andrew

1999 The Legend of the Golden Boat: Regulation, Trade and Traders in the Borderlands of Laos, Thailand, China and Burma. Richmond, Surrey: Curzon Press.

Yeh, Rihan

2017 "La Racha: Speed and Violence in Tijuana." Signs and Society 5, no. S1: S53-S76. https://doi.org/10.1086/690088. 